\title{
Linguistic Analysis of Insta, Twit Posts and LJ Blogs in the Context of their Functions (Based on the Russian Language)
}

\author{
https://doi.org/10.3991/ijim.v15i05.20013 \\ Olga Novikova ${ }^{(凶)}$, Yuliya Kalugina, Albina Mustafina, Irina Edeleva \\ Higher Education Bashkir State Agrarian University, Ufa, Russia \\ novikovaolg5erambler.ru
}

\begin{abstract}
The present article is concerned with identifying the linguistic and extralinguistic features of Instagram, Twitter, and Live Journal hypertexts, depending on their functional focus. The relevance of the topic is due to the need for a more detailed study of Internet communication from the point of view of functional and stylistic aspects. The study provides a comparative analysis of Instagram, Twitter, and Live Journal online services based on the Russian language material. The following methods of analysis were used: the hypothetical-deductive method, methods of linguistic analysis, and the survey method. The results are correlated with the questionnaire data on the studied problem. The article discusses graphic, lexical, stylistic, syntactic, and spelling features. The authors conducted a comparative analysis of the hypertexts of Instagram, Twitter, and Live Journal online services in the context of their functions; identified linguistic and extralinguistic features of the hypertext of the services under study; established the relationship between the language of the text and the function implemented. It has been established that all three online services perform, first of all, a communicative function, which is expressed through the use of slang, vernacular, online discourse vocabulary, graphic means, markers of increased emotionality, recreation of a specific accent / dialect, spelling and punctuation violations, incomplete, unextended sentences. Along with the socialization function, Instagram performs the function of self-presentation, for the implementation of which the authors of publications resort to linguistic creativity. Unlike Instagram, Twitter, and Live Journal fulfill a more political function, expressed in stylistic devices such as metaphor, comparison, irony, hyperbole, and repetition. The results were verified using a questionnaire survey conducted among Russian students. The questionnaire survey shows that the dominant function of the analyzed online services is socialization, which correlates with the function of self-presentation. The survey results demonstrate that stylistically reduced vocabulary (slang, jargon) has become the norm of modern Internet communication.
\end{abstract}

Keywords - Internet communication, hypertext, functional potential, linguistic and extralinguistic features, blog, post, language norm 


\section{Introduction}

At the present stage of social development, a new area of public conscience and communication has appeared: the worldwide information medium - the Internet, which is reflected in the selection and consolidation of particular language means typical of the online text format - hypertext. [1,2] This type of text as a type of mass communication text is characterized by features of various functional styles, its own choice of words, the principles of their use, the predominant use of certain syntactic structures, the peculiarity of using figurative means of language, the practice of various methods of communication between parts of the utterance, etc. [3,4] Researchers note that Internet posts "blur the differences not only between monologue and dialogue but also between oral and newspaper forms of speech, between official and unofficial communication, between socially and individually focused communication”. [5-7] Modern hypertext, as a rule, is characterized by expressiveness, which is implemented through extralinguistic means. Thus, spectacularity, the tendency for demonstration, and entertainment are peculiar for the texts of the online format.

Linguists consider the language of mass communication from a variety of perspectives. Within the cognitive approach framework, the online media text is studied as a scheme, the components of which are concepts and notions of objects and phenomena of the external world and the relations between these objects and phenomena. Media schemes are defined as online services used to create, transmit, perceive, and process messages. [8]

From the point of view of the semiotic approach, the text of mass communication can be considered as one or several sign systems that use various semiotic codes, including verbal and non-verbal components represented by paralinguistic means. [911] In addition to traditional iconic paralinguistic tools, such tools as hyperlink style, animation, audio, and video inserts are popular in online texts. Anisimova considers all the texts that use paralinguistic means to be paralinguistically active. [12]

A large group of paralinguistically active texts includes creolized texts. In our research, we understand online hypertext as a polycode or creolized formation that combines sign diversity (verbal and nonverbal components). [13]

Other sign systems include photos, images, diagrams, tables, logos, pictograms, and audio inserts widely distributed on the Internet. Tungga sees creolization as a tool for linguistic and cultural preservation and language revival through hashtags, quotes, and images. [14]

Creolized texts are divided into three groups that differ depending on the presence of the image and its connection with the verbal part. The first group consists of texts with zero creolization, i.e., texts that do not contain an image. The second group includes texts with partial creolization in which the verbal part is relatively autonomous and does not depend on the image. The third group is represented by texts with complete creolization, in which the verbal part cannot exist independently and is focused on the image or refers to it, and the image acts as an obligatory element of the text. [12] 
Based on the communicative and pragmatic norm, the text of the online format is a paralinguistically active text with full creolization, including a verbal component, an image, and an accompanying signature.

This paper analyzes three of the most popular online services - Instagram, Twitter, and Live Journal - to investigate them as a special form of virtual communication. The object of this research is hypertext as a set of many branching texts of online format connected by cross-links. The research subject is the functional potential and linguistic and extralinguistic features of modern hypertext based on the material of the considered online services.

The Internet is a multilingual sphere where people from different backgrounds and social groups conduct the business, study, and communicate informally. The cosmopolitanism of the World Wide Web cannot but affect the selection of language means for interaction. [15] The relevance of this research is due to the attention to Instagram, Twitter, and Live Journal microblogging potential in information dissemination in terms of their functions, extralinguistic and linguistic means of expression, as well as the ability to customize based on the needs of communicants.

As a result of observations, the following hypothesis was put forward: grammatical and stylistic presentation of hypertexts in Instagram, Twitter, and Live Journal directly depends on their functional potential.

The aim of the study is to identify the relationship between the linguistic and extralinguistic features of the analyzed hypertexts and their functional focus. The stated aim shapes the solution for the following objectives:

1. To conduct a comparative analysis of the hypertexts of the studied online services in the context of their functions.

2. To identify linguistic and extralinguistic features of the hypertext of Live Journal, Twitter, and Instagram services.

3. To establish a link between the language of the text and the implemented function.

4. To verify the results obtained using a questionnaire survey of Russian students.

The novelty of the study is that Russian-based Live Journal, Twitter and Instagram were compared to determine the dependence of the language of posts and blogs on their functional potential. For the first time, the results of the linguistic analysis of the studied hypertexts correlate with the survey data on the studied problem.

\section{Methods}

\subsection{Research design and sample}

Blogs, posts, and comments taken from Instagram, Twitter, and Live Journal social services for 2020 were the material of this study. Of particular interest were blogs, posts, and comments that reflect topical events of the current year and occupy top positions in the news feed of the analyzed services. The corpus of examples consisted of about 300 units collected by the continuous sampling method. Both quantitative and qualitative methods were used for the data analysis. 


\subsection{Data analysis}

The aim and objectives of the study led to the use of the following methods of analysis: the hypothetical-deductive method, methods of linguistic analysis, and the survey method. [16] The hypothetical-deductive method is leading to research. It provides a scientifically based construction of the research course. This method was used at the stage of making assumptions, initial observations, collecting and selecting research material and formulating a hypothesis, and at the stage of verifying the hypothesis and generalizing the data obtained.

Verification of the hypothesis that the grammatical and stylistic presentation of the Instagram, Twitter, and Live Journal hypertexts depends on their functional potential is determined using the methods of linguistic analysis and questionnaire survey.

The linguistic analysis method aims to study linguistic and non-linguistic means of different levels in the hypertext system from their perspective of their functions and compliance with language norms. Linguistic analysis of linguistic and non-linguistic means includes studying the graphic, lexical, syntactic, and stylistic presentation of the text, the study of creolization means, and the degree of intertextuality. This method was widely employed while analyzing the study material.

The survey method involves collecting information from respondents using a specially designed list of questions (questionnaire) compiled by the authors to determine the functional focus of the posts and their language presentation.

The questionnaire survey was conducted in April 2020 among students of Bashkir State Agrarian University using the Google Forms service. Among the 1st year students of bachelor's and master's degree programs, 145 respondents (Russian and international students), regardless of gender, voluntarily agreed to take part in the survey. They were asked to answer 14 questions. Multiple choice and open-ended questions were used in the survey. The survey was used to find out which of the services under study (Instagram, Twitter, and Live Journal) respondents are familiar with and actively use, and for what purpose, what is the role of hashtags/ tags in online communication, what graphic and morphological means (slang, abbreviations, neologisms, emoticons) respondents use when posting, whether the authors of messages pay attention to the competent (normative) speech.

\subsection{Statistical processing}

The data obtained were processed using elements of the statistical analysis method by the online tool Google Forms. This tool provides automatic processing of respondent responses in real-time and presents survey results in charts and automatically created Google tables. The responses of all respondents were found to be relevant.

\section{$2.4 \quad$ Research limitations}

The following limitations were identified during the survey: the quantitative parameter - 145 people, the qualitative parameter - 1st-year students of bachelor's and master's degree programs of Bashkir State Agrarian University, research material limitation - Instagram, Twitter, and Live Journal online services. 


\subsection{Ethical issues}

All responses are anonymous and do not include the respondent's full name. The survey results are available only to the respondents and questionnaire creators - the authors of the article. This data are not shared with third parties.

All data were legally received and transmitted to https://docs.google.com/forms/u/0/, i.e., with the voluntary consent of their owners and in compliance with their legal rights (including compliance with the Federal law "On personal data" dated 27.06.2006 No. 152-FZ).

\section{Results and Discussion}

Analysis of the functional potential of posts and blogs showed a certain dependence of the hypertext language on the implemented function.

Posts and blogs are based on a communicative function that can be viewed from two perspectives: communication with existing acquaintances and communication to meet new people and expand one's audience. This format of communication is represented by the following means.

Slang

Ах, да, прикольный момент. <..> Я сразу узнал его и понял, что шцас появится Боб. (LJ)

Спасибки; щุа (Insta)

\section{Vernacular}

но как тока Ефремов вякнул, шо он не против Терана, так про него ни слуху, ни духу! (Twit)

\section{Vocabulary of online discourse}

Все никак не мог понять, откуда
$A h$, da, prikol'nyj moment. <...> Ja srazu uznal ego $i$ ponjal, chto shchas pojavitsja Bob - Ah, Yes, a cool moment. <...> I immediately recognized him and realized that Bob would appear right now.

Щаc / shchas instead of normative сейчac / sejchas (now).

Spasibki; scha instead of normative spasibo (thanks) and sejchas (now).

No kak toka Efremov vjaknul, sho on ne protiv Terana, tak pro nego ni sluhu, ni duhu - but as soon as Yefremov spoke indistinctly that he was not against Teran, there hadn't been a cheep of him! Toka instead of normative tol'ko (as soon as); vjaknul (past of vjakat' - disapprovingly, disparagingly speak about someone); sho instead of normative chto (what).

I couldn't figure out where Lisa got all 
Лиза берет все эти словечки про подписки, лайки и инстаграм ...(Insta)

Все фото и видео по нашему путешествию помешу в окошко вечных сториз, как многие из вас и просили (Insta) those words about subscriptions, likes, and instagram from ...

All photos and videos of our journey will be placed in the window of eternal stories, as many of you have asked

\section{Graphical means (Extralinguistic features)}

И всего-то надо надеть маску. Но он не наденет. НИ $3 А$ ЧТО НА СВЕТЕ. Good for him, как говорят у нас в Канзасе. (LJ)

Написано почти 160 лет назад Что изменилось? НИ_ЧЕ_ГО! (Twit)

Реально КРУТО! (Insta)

«Только пост на 45 фотографий белочки и 50 абзацев өлg вы виде ее взгляд на 15-өй фөтографии?!»... (LJ)

Вас узнали на улице пепшия читатели? (LJ)
All you have to do is put on a mask. However, he won't wear it. NOT FOR THE WORLD. Good for him, as we say in Kansas

Written almost 160 years ago What has changed? NO_THING!

Really COOL!

"Just a post on 45 photos $\theta$ f a squirrel and 50 paragraphs emg did you see her took on the 15th photo?!"...

Did the police readers recognize you on the street?

The use of strikethrough text is typical for $L J$ blogs. As a rule, a statement that categorically expresses the author's opinion is marked by a strikethrough. Such a statement is often accompanied by an uncrossed statement that explicates a similar opinion but is expressed in a milder, tolerant form.

Markers of increased emotionality (A way to express feelings, emotions, and moods using letter combinations (a set of letters), sometimes instead of emoticons):

Это второй этаж? Второй, гггг (Insta)

Блииин, я тоже хочууу! Каккрасиииво!!!йееееможнааааа (Insta)

мммм, фото огонь, такие красивые (Insta)
Is this the second floor? The second, gggg

Oh sh-suuugar, I also waaant! How beautiful!!! jeeee it's possible

Mmmm, photos are straight fire, so beautiful 
Paper-Linguistic Analysis of Insta, Twit Posts and LJ Blogs in the Context of their Functions...

Aaaaaа a, с ума сойти (Insta)

Даaаa (Insta)

Bom это daaaaaaaaaaaaaaa (Insta)

\section{Simulating a specific accent/ dialect}

Ощень короще)) (Insta)

Ощчень весьма даже (Insta)

обзывается и шо (Insta)

Гарик джян, ть СУПЕР!!!! (Insta)
Aaaaaaah, crazy

Yeeeah

Vot eto daaaaaaaaaaaaaaa (Lo and behold!)

Oshhen' koroshhe)) instead of normative Ochen' horosho (Very good; Very well)

Oshhen' ves'ma dazhe (Very even)

obzyvaetsja $i$ sho instead of normative obzyvaetsoa $i$ chto (calls names and what)

Garik dzhjan, ty SUPER!!!!, where dzhyan means dear in Armenian (Dear Garik, you're SUPER!!!!)

\section{Violation of spelling and punctuation}

Теперь я знаю как мы выглядем со стороны (Insta)

Teper' ja znaju kak my vygljadem so storony (Now I know what we look like from the outside).

Vygljadem vs. normative vygljadim (look like), there must be a comma before kak

Выбрались на прогулку. Дошли пешкой от нашего нового дома (Insta)
Vybralis' na progulku. Doshli peshkoy ot nashego novogo doma (We went for a walk. Went by a pawn from our new home).

By a pawn vs. normative on foot.

Incomplete, unextended sentences in which the content of the message comes first, rather than its grammatical design:

Я падаю, настоящая девушка, I'm falling, real girl, facial expression выражение лицуа (Insta)

Such cases are associated with implementing the principle of linguistic economy, which increases the speed of interaction between interlocutors. Compensatory prag- 
matic strategies ("semiotics of compensation") are also considered in the works of foreign authors. [17-19]

Analysis of examples shows that the communicative function is most clearly represented in Instagram and is dominant since this application is based on the idea of socialization, in contrast to LiveJournal and Twitter, whose function is public blogging (online diary) and instant reaction to events, respectively.

The variety of means of expression allows authors of blogs and posts to attract and hold the reader's attention, make the text bright and memorable, and display the desired information to the fullest extent possible. This conclusion is confirmed in the work by Gustilo and Dino. The authors believe that acronyms, emoticons, truncation of unnecessary information, and ways of transcoding information in an utterance contribute to more effective and expressive message transmission, compensating for the lack of nonverbal means of communication. [20]

To make speech more figurative and even metaphorical, authors often use phraseological units:

Масла в огонь таких подозрений подливали встречи дипломатов Генконсульства США (которое Эдвард Сноуден назвал «станцией ЦРУ») с лидерами протестуюших, размахивание американскими флагами на протестных акииях и призывы оппозиции $к$ властям США ввести санкции против КНР за Гонконг. (LJ)

П. приказал остановить рост вирус взял под козырёк. (Twit)
Such suspicions were fueled by meetings between diplomats of the US Consulate General (which Edward Snowden called a "CIA station") and protest leaders, waving American flags at protest actions, and calls from the opposition for the US authorities to impose sanctions against the PRC for Hong Kong.)

The verb 'fuel' is in the meaning "pour oil on flames" - aggravate, worsen.

$P$. ordered to stop growth - the virus snapped a salute.

Metaphor affects the reader's imagination, forms a figurative representation of the world, makes the image more vivid and visual, and represents an individual author's model of the world:

Они просто начали бояться вместе и вместе надеяться, что вторая волна (коронавируса - прим. авторов) не обрушится на токио десятиметровым цунами, а отступит быстро $и$ без жертв, будто и не было ее вовсе. (LJ)

Просыпаюсь сегодня утром от еле сльишимого звона. Сначала не сообразил, а потом понял, что это целостность нашего суверенитета
They just started to be afraid together and hope together that the second wave (coronavirus - authors' note) will not hit Tokyo with a ten-meter tsunami but will retreat quickly and without casualties, as if it did not exist at all.

I wake up this morning to a faint ringing sound. At first, I didn't realize, but then I realized that it was the integrity of our sovereignty that began to 


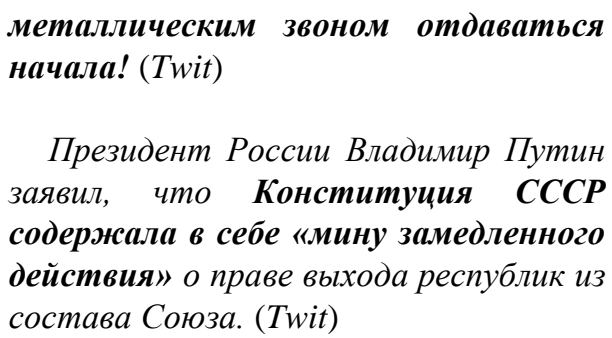

Президент России Владимир Путин заявил, что Конституция СССР содержала в себе «мину замедленного действия» о праве выхода республик из состава Союза. (Twit)

reverberate with a metallic clang!

Russian President Vladimir Putin said that the Constitution of the USSR contained a "time bomb" on the right of republics to secede from the Union.

Comparison as a stylistic device serves as the basis for the deployment of the image, as a result of which the subject matter renders concrete becoming more evident and expressive. Often authors combine comparison with irony using two types of lexical meanings: subject-logical and contextual, based on contrast:

Подойдите ближе, - сказал он с таким пафосом, будто на Японию вот-вот нападет Ким Чен Ын, а нам выпал шанс стать первыми камикадзе, кого Абэ отправит на дикий Север в последний путь. ( $(L J)$

По информащии Роспотребнадзора за прошедшие сутки в Крым прибыло 1460 человек: авиатранспортом - 275, железнодорожным - 147, по Крылмккому мосту - 1030, из Украины - 13. А 2 млн. крымчан, глядя из окон своих квартир, пытаются разгадать это странное слово “самоизоляциия". (Twit)

To enhance the expressiveness of the statement and create a strong emotional impression, the authors of publications use hyperbole and repetitions:

На дорогу вернулись люди. Их было много. Слишком много. Апокалиптично много. $(L J)$

Они и в натуре что ли, под наркотой? «Ситуация с к-вирусом в России уникальна» - заявила Путину глава Роспотребнадзора Анна Попова. $y$ нас $u$ народ уникальный, $u$ президент уникальный, $и$ экономика уникальная.(Twit)
Come closer, he said with such pathos as if Japan is about to be attacked by Kim Jong-UN, and we have a chance to become the first kamikazes that Abe will send to the wild North for the last time.

According to Rospotrebnadzor, 1460 people arrived in Crimea over the past day: by air - 275, by rail - 147, by the Crimean bridge - 1030, from Ukraine 13. And 2 million Crimeans, looking out of their apartment windows, are trying to unravel this strange word "selfisolation".
People returned to the road. There were many of them. Too many. Apocalyptically many.

Are they actually / for real on the drugs / druggy / drugged? "The situation with the c-virus in Russia is unique," Anna Popova, head of Rospotrebnadzor, told Putin. We have a unique people, a unique President, and a unique economy. 
As we can see from the above examples, such stylistic devices as metaphor, comparison, irony, hyperbole, and repetition, as well as the use of phraseological units, are reflected in the implementation of the political function, the main purpose of which is to form a political world view, inform and explain. They are presented mainly in $L J$ blogs and Twit posts. Some works describe the dependence of linguistic means on the communicative situation related to politically and socially significant events [21].

It should be noted that the stylistic devices described above can also be found in Insta posts, but due to the specifics of this online service, they perform a different function, namely the function of self-presentation in order to attract attention to one's account.

\section{sta) \\ Наконец-то прям гора с плеч. (In- \\ Выгуливаю новый иявет волос) пока} только на балконе. (Insta)
Finally, a real mountain off your shoulders.

Walking a new hair colour) while only on the balcony.

Since people are self-centered by nature, self-expression is an important component of both real and virtual life. They create the image they want and learn to express their thoughts structurally following the online service format. To create a unique image and attract attention to their account, authors of publications resort to linguistic creativity using various devices in speech, such as slang, borrowings, neologisms, using foreign vocabulary in a Russian sentence, coining new words, deliberately breaking spelling and punctuation, using rhyme, allusion and wordplay. Many researchers note that such linguistic creativity gives online texts humor, irony, and pronounced evaluativity. [22,23].

\section{Slang}

Ни полуагрессивные марксисткифеминистки, ни черныцй чувак в красной майке с серпом и молотом, ни мутный крендель, что пьттался запретить съемку призывая уважать сакральность пространства. (LJ)
Neither semi-aggressive Marxist feminists, nor a black dude in a red t-shirt with a hammer and sickle, nor a dopy that tried to ban the shooting calling for respect for the sacredness of space.

Чувак / chuvak means dude, мутный крендель / mutnej krendel' - dopy / oddbod/wierdie.

\section{Borrowings (Interference) $\rightarrow$ Neologisms}

Многим, кто пишет и говорит об этом, уже довольно много лет, часто больше, чем мне, и было бы странно ожидать от них, что в свои шестьдесят они начнут перестраивать свое айдентити. ( $L J)$
Many people who write and talk about this are rather old, often older than I am, and it would be strange to expect them to start rebuilding their identity in their sixties.

Айдентити / ajdentiti - loan transla- 
tion of the English word identity.

Куда написать чтобы японская тугезер стала опеннингом к новому сезону бездомного Бога мне для подруги (Twit)

Tру стори, кстати. Вынуждают меня подвергать всех излишнему риску; Кулстори о том, как $я<\ldots>$. (Twit)

\section{Каждый день при мэйке (Insta)}

Шикарно, умеем же, когда захотим подскажите, плиз, кто знает, в какое время свето-музыкальное шоу? (Insta)

Майнгад - какая красота (Insta)

Зафиксировал шейминг (Insta)

\section{The use of English words}

А мне все время кажется, что вчера фейсбук начал бороться с hate speech, сегодня редактор журнала уходит в отставку <...>. $(L J)$

\section{Creating new words}

Правда, $к$ стойке выцдачи по-
Where to write to for the Japanese together to become an opening for the new season of homeless God for my friend. тугезер / tugezer - from the English word together; опеннингом / openingom - from the English opening.

True story, by the way. They force me to expose everyone to unnecessary risks; Cool story about how $I<\ldots>$.

Tpy cmopu / tru stori - loan translation of the English true story. Кулстори / kulstori - loan translation of the English cool story.

\section{Every day with make-up}

Ппри мэйке / pri mejke - shortening of the English with make-up.

Chic, we can do it when we want to tell me, please, who knows what time is the light and music show?

Плиз / pliz - from please.

Maingad - what a beauty.

Maйнгад / maingad - from mein and God.

Fixed shaming.

Шейминг / shaming - from shame.

And it always seems to me that yesterday Facebook started fighting hate speech, today the magazine's editor is resigning <...>.

The English phrase hate speech is used in the Russian sentence.

However, the delivery desk is still al- 
прежнему пускают только в масках, подносы выдают картонные, одноразовые, да и в Ашане на входе просят маски надеть - но общуий оживляж прямо заметен. (LJ)

Поэтому если вдруг в сельпо не завезли обычный, без сочных кусочков хрюктов йогурт, то можете взять $u$ кефир - самое главное сцедить сыворотку. $(L J)$ lowed only in masks, only are cardboard disposable trays are given out, and in Auchan, at the entrance, they ask you to wear masks - but the general animation (ozhivljazh) is directly noticeable.

Ozhivljazh: the merger of the words "lively" and "hype".

Therefore, if they suddenly did not bring the usual yogurt without juicy pieces of grunts (hrjuktov) to the village general stores, then you can take kefirthe most important thing is to strain off the whey.

Hrjuktov: the merger of the words "grunt" and "fruits".

\section{Intentional violation of spelling and punctuation}

Учёные собираются проделать опьты Бога, претворить свет в материю ... кот стукнул по какой то жылизяки и в ином конце комнав управлении чото звякнуло , кот насторожылся / Сие никада низнаишь чо буит если стукнуть сию жылизяку, сия жылизяка по воспроизводству

ниожьданнастяф...(Twit)
Scientists are going to make the experiment of God, to transform light into matter ... the cat knocked on some metalware and something tinkled at the other end of the control room, the cat was alert / You never know what will happen if you hit this metalware, this metalware is for producing surprises...

There must be hyphen in какой то / kakoj to = kakoj-to (some), чото / choto = chto-to (something); there are spelling mistakes in жылизяки / zhylizjaki = zhelezjaki, комнавы управлении / komnay upravlenii = komnaty upravlenija (control room); насторожылся / nastorozhylsja = nastoroshilsja (was alert); никада низнаишь / nikada niznaish' = nikogda ne znaesh', чо буum / cho buit = chto budet (what will happen), ниожыданнастяф / niozhydannastjaf = neozhidannostej (surprises); two commas are missing before cho and esli.

\section{The use of rhyme}

Я по тебе грущу как сметанка по бориу (Insta)
Ja po tebe grushhu kak smetanka po borshhu (I miss you like sour cream over borscht).

Grushhu and borshhu are rhyming words. 
Только липтон казаку в степи напиток

Только ролтон казаку в степи обед (Twit)

\section{Allusion}

Дело в том, что власти КНР всегда подозревали, что всё это протестное «ж-ж-ж» неспроста, что за спинами протестующих

скрываются враждебные силь (не будем показывать пальцем на США), и что Америка стремится за счёт протестов раскачать ситуацию в городе и иметь возможность давления на Kumaй. (LJ)

Вклады населения забрать нельзя ocmaвumb (Twit)

Ночь, улища, фонарь... дождь (Insta)

\section{Wordplay}

Мерзлота - не вечная. Вечна только мерзота. (LJ)
Only Lipton is a drink to a Cossack in the steppe

Only Rolton is lunch to a Cossack in the steppe.

These rhyming lines are an allusion to Kazach'ja - the famous Russian song by A. Rozenbaum.

The fact is that the Chinese authorities have always suspected that all this protest " $z h-z h-z h$ " is not for nothing, that hostile forces are hiding behind the protesters (we will not point a finger at the United States), and that America is trying to shake the situation in the city through protests and be able to put pressure on China. - An allusion to a famous phrase Jeto «zh-zh-zh» - nesprosta! (This "zh-zh-zh" is not for nothing!) from Winnie-the-Pooh by A. A. Milne.

Deposits of the population cannot be taken away - an allusion to a popular expression to describe two mutually exclusive possibilities, one of the famous examples of amphiboly: kaznit' nel'zja pomilovat' (pardon impossible to execute).

Night, street, lantern... rain - an allusion to the first lines of the famous poem by A. Block: "A night, a street, a lamp, a drugstore..."

Merzlota - ne vechnaja. Vechna tol'ko merzota. (Permafrost is not everlasting. Only the abomination is everlasting.). Merzlota (permafrost) differs from merzota (abomination) by letter $l$. 
The self-presentation function is closely correlated with the marketing function responsible for promoting products and services on the market, conducting PR campaigns and generating revenue through advertising, and promoting one's account and web resources.

Взаимный фолловинг! (Twit)

Что и следовало ожидать. Мой акк Анатолич@dogl00000 заблокировали. Читайте меня здесь. Прошу ретвит. (Twit)

Смотрите, что слушаете! Ссылка в cmopuз! (Insta)

\author{
Vzaimnyj folloving! (Mutual follow- \\ ing!)
}

Which is to be expected. My acc Anatolich@dogl00000was blocked. Read me here. Please retweet.

Watch what you're listening to! The link is in stories!

Thus, all three analyzed online services equally perform the function of selfpresentation, which is implemented in language terms through a variety of lexical and stylistic means.

At the same time, the memoir feature is typical for the Live Journal service. LJ bloggers often keep records in order not to forget the details of certain events in their lives or to think about them later, thus creating a kind of deferred communication with themselves. [24]

Analysis of blogs made it possible to identify the following models of text presentation:

1. Question and answer (a kind of simulation of a dialogue with the reader)

Расизм - это плохо? Да, плохо. Надо помогать бедным? Надо. (LJ)

\section{The use of dots}

Конечно, такие приношения можно посылать и богам напрямую, но подумайте сами - если у вас совсем рядом с богом есть любимый дядюшка, не лучше ли отправить деньги ему, чтоб он там за вас похлопотал?.. (LJ)
Is racism a bad thing? - Yeah, it is. Do we need to help the poor? Yes, we do.

Of course, such offerings can be sent directly to the gods, but think for yourself - if you have a favourite uncle very close to God, wouldn't it be better to send money to him so that he can take care of you there?

This device emotionalizes the blog text and sensifies continuing communication; also, with the help of ellipses, the blogger pauses to get feedback from the reader.

To confirm the above observations, the authors conducted a questionnaire survey to identify the popularity of Instagram, Twitter, and Live Journal among Russian students and analyze the dependence of linguistic and stylistic features of hypertexts on their functional focus.

One hundred and forty-five respondents from Bashkir State Agrarian University (Ufa, Russia) took part in the survey. Figure 1 demonstrates the use of the analyzed 
online services by respondents, where the horizontal axis represents the number of respondents, and the vertical axis lists the services.

3. What service do you actively use?

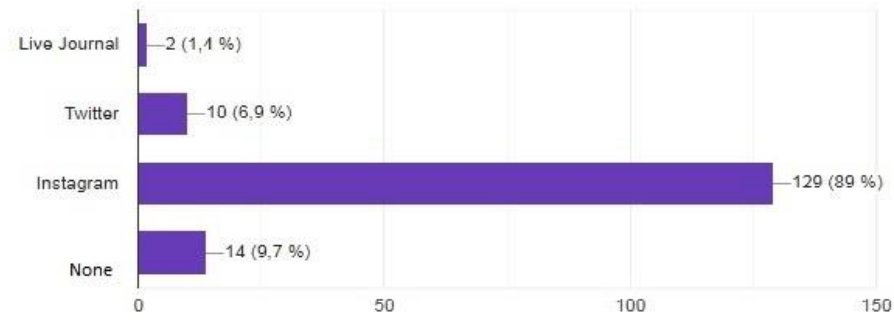

Fig. 1. Respondents' preferences in using online services, people / percent

The survey results showed that Instagram is the most popular app for Internet communication $-89 \%$ of respondents are active users. Twitter is the second most popular site $(6.9 \%)$. Statistics shows that none of the respondents are registered in Live Journal, and only $1.4 \%$ of respondents use this service as unregistered users. Obviously, this can be explained by the specific format of this platform and the age of the survey participants. It should be noted that $9.7 \%$ of respondents do not use the analyzed services at all.

The functional potential of the analyzed online services can be described as follows: $80.1 \%$ use Instagram, Twitter, and Live Journal for socialization, $69.5 \%$ - for transmitting and receiving information, 5.7\% - for product promotion (advertising), and $0.7 \%$ pursue such goals as expressing political views and positions, working with children, viewing memes, entertainment, storing photos, leisure, and other (see Figure 2 , where the horizontal axis shows the number of respondents and the vertical axis represents the functional potential of the services).

4. What do you use Live Journal, Twitter, and Instagram for?

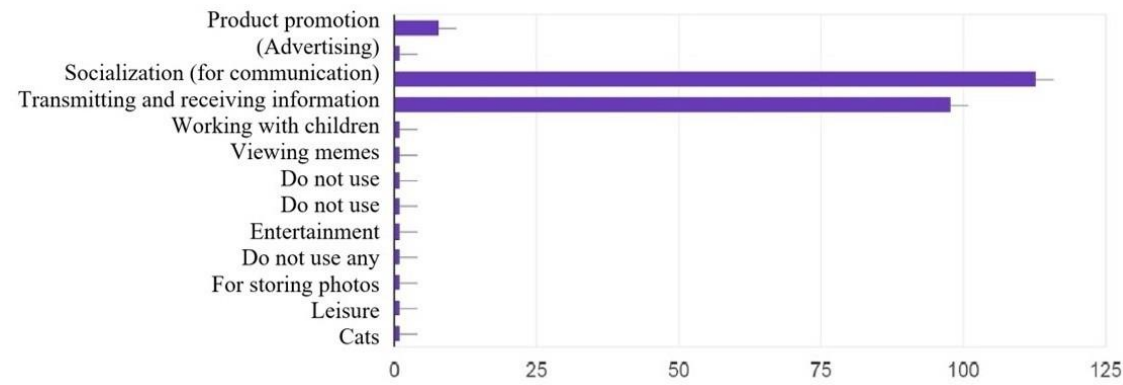

Fig. 2. Functional potential of the analyzed online services (survey results), people 
It should be noted that $50.3 \%$ use the analyzed online services to keep up to date with news and comment on them. About as many (49.7\%) use Instagram, Twitter, and Live Journal to get information without feedback (comments, likes). $38.5 \%$ of respondents said they do not like to write posts and just post photos. About a third of respondents $(35.7 \%)$ make reposts and retweets if they are interested in the information received. And only $7 \%$ of respondents actively post and blog. This ratio of the verbal and non-verbal can be explained by the type of personality of respondents (auditory-visual, introvert-extrovert) or by the dominant type of speech activity (productive-receptive) (see Figure 3, where the horizontal axis shows the number of respondents and the vertical axis represents the scope of activities in the online services). Such an analysis of the user's "digital footprint" permits making a psychological portrait of the individual. [25] Also, the nature of activity in the service may depend on the user's objectives and tasks.

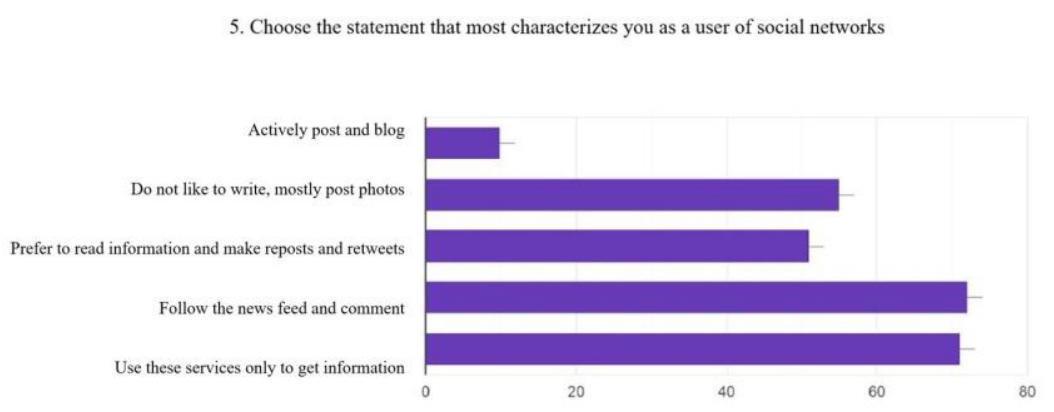

Fig. 3. The nature of user activity in online services (survey results), people

$45.1 \%$ reported that they pay attention to the correctness of speech and always correctly present posts and blogs following the language norm, $59.9 \%$ try to write correctly, and only $2.8 \%$ admitted that they write with errors.

The most interesting were the answers to questions related to linguistic creativity. Accordingly, the most used techniques include the following:

- Abbreviations including in English (мб - может быть / mb - mozhet byt' (maybe), спс / сиб - спасибо / sps / sib - spasibo (thank you), крч - короче / krch koroche (in short), всм - в смысле / vsm - v smisle (in the sense of), нз - не знаю / nz - ne znaju (I don't know), чд - что делаешь / chd - chto delaesh' (what are you doing), лн - ладно / ln - ladno (okay), чсв - чувство собственной важности / chsv - chuvstvo sobstvennoj vazhnosti (arrogance, self-importance), лс - личные сообщения / ls - lichnye soobshhenija (personal messages), ty ( thank you), glhv (good luck, have fun), BFF (best friend forever), k (thousand);

- Abbreviations formed as a result of language interference (бзв - bzv (by the way), свэг - swag (cool), qq (peep-bo), lol (funny, cool); 
- Truncations: ава - ava (avatar), гиста - gista (histology), анат - anat (anatomy), стипа - stipa (from stipendija - scholarship), зач - zach (from zachem - what for), поч - poch (from pochemu - why), уник - unik (University);

- Borrowings, many of which have got a foothold in slang, e.g. кэш - kjesh (from cash - money), изи - izi (easy), го - go (from let's go - start, come on), рили - rili ( from really - in fact), чилить - chilit' (from chill - relax), флексить - flexit' (from to flex - have fun, move), юзать - juzat' (from to use), рофлить - roflit' (from ROFL - Rolling On the Floor Laughing), лайтовый - lajtovyj (from light easy), найс - nais (from nice), фастом - fastom (from faster), хайп - hajp (from hype - attract attention), чекнуть - cheknut' (from to check), дэнсить - djensit' ( from to dance), руинить - ruinit' ( from to ruin - destroy), челлендж - chellendzh ( from challenge - test), муд - mud (from mood), фейк - fejk (from fake - lie), фейл - fejl (from failure), кринж - krinzh (from cringe - ashamed, disgusting), вайб - vajb (from vibe - atmosphere), краш - krash (from crush - the person you are in love with), бро - bro (from brother - a good friend), тян - tjan (from Japanese - a beautiful, sweet girl), кек - kek ( from Korean -malicious laughter);

- Russian slang / jargon: чел / чувак - chel / chuvak (person, man), жиза - zhiza (from zhizn' - truth of life, life situation), жесть - zhest' (from zhelezo (tin) - horror), прикид - prikid (outfit - clothes), параллельно - parallel'no (in parallel - all the same), базару нет - bazaru net (there is no bazaar - necessarily, of course), предки - predki (ancestors, parents), красава - krasava (from krasivyj (beautiful, good) - well done), зашквар - zashkvar (ignominy, nasty thing), opy - oru (I am yelling - laughing at something very loudly, at the top of my voice), хата - hata (hangout, jam).

The identified cases of language interference correlate with the idea of "network multilingualism" described in the paper by Androutsopoulos. [26]

Although the online services under study have taken the scientist attention since their inception, a review of literature sources showed that hypertext analysis was mainly based on the English language material. [27,28] However, since most users are non-English speakers, the issue of language interaction in a globalizing world is of interest. One of the first papers analyzing the place of other languages in the blogsphere was the study by Herring et al. [1] At the same time, there is not enough data to determine the specifics of the language of posts and blogs based on the Russian language. A number of linguists study individual discourses of social networks to define their structural and content features and linguistic/non-linguistic "constitutive elements". [29-31]

In the research by Kiuru, [32] Volokhonsky, [24] Goncharova, [33] the functional potential of online services is considered in isolation from the linguistic and extralinguistic characteristics of hypertexts. Some papers reveal the intentional and thematic focus of Insta and Twit posts. [34] Functional and stylistic features of microblogging are considered in the work of Idowu-Faith. [35]

There are various approaches to the theory of hypertext research and analysis, as well as to understanding the term itself. The study of this problem is associated with 
such experts in metatext as Bakhtin, Vezhbitskaya, Genette, Lotman, Riabtseva, Perfil'eva, Shaimiev, Crismore, Hyland, Vande Kopple, et al.

In this article, hypertext is considered in its particular manifestation on the material of the studied online services (posts in Twit and Insta and blog entries in LJ). This type of text is notable for certain stability, on the one hand, and for certain mobility on the other hand. [32] Its main features are a limited number of characters, creolization, intertextuality, linearity/ non-linearity, synchrony / asynchrony, and the use of hashtags. A detailed analysis of these features of LJ, Twit, and Insta texts is presented in an earlier study. [36]

The use of a wide variety of linguistic and non-linguistic means to transmit the information due to restrictions on the number of characters in a message requires an adequate understanding by the recipient. However, it should be emphasized that the author's creativity often leads to cognitive overload and, as a result, to the incomplete understanding of the text. [37] Several reasons account for the creation and use of the analyzed words and phrases: 1) limited discourse - Internet-mediated communication; 2) the segment of respondents - students; 3) the desire of users to feel like co-creators of the lexical component of communication in order to make their speech more emotional and expressive, give it a distinctness and show that they are in a trend.

\section{Conclusion}

The main features of hypertext are stylistic antihomogeneity, a combination of external features such as cross-references in the text, creolization, various structural and graphic presentation, interactivity, and others. When considering the features of the functional potential of the hypertext of the analyzed services, an anthropocentric approach to the text is taken into account, in which it is regarded as combined with extralinguistic factors including socio-cultural, pragmatic, psychological, and other aspects.

A comparative analysis of the hypertexts of Live Journal, Twitter, and Instagram revealed linguistic and extralinguistic features of hypertexts depending on their functional focus. Thuswise, first of all, all three online services perform a communicative function. Along with the socialization function, Instagram serves a self-presentation function and is often used for advertising products or services. Unlike Instagram, Twitter, and Live Journal serve the political function to an increasing degree, with Live Journal often used as a platform for keeping diaries, thus performing the function of memoirs.

The communicative function (socialization function) is expressed through slang, colloquialisms, online discourse vocabulary, graphic tools, markers of increased emotionality, simulation of a specific accent/ dialect, violation of spelling and punctuation, incomplete, unextended sentences. Such stylistic techniques as metaphor, comparison, irony, hyperbole, and repetition, as well as the use of phraseological units, are reflected in the implementation of the political function. To implement the function of self-presentation, authors of publications resort to language creativity, use slang, borrowings, neologisms in speech, use foreign vocabulary in Russian sentences, coin new 
words, intentionally violate spelling and punctuation, use rhyme, allusion, and wordplay.

The questionnaire survey results also correlate with the analysis of the studied Instagram, Twitter, and Live Journal hypertexts. It should be noted that the dominant function of socialization $(80.1 \%$ ), which is associated with the function of selfpresentation, is implemented in the analyzed hypertexts through stylistically reduced vocabulary (slang, jargon), which, unfortunately, is the norm of modern Internet communication. The obtained data can serve as the subject of further analysis in the framework of language norm studies. The study can have a great impact on such urgent issues as ecology of language acquisition and language socialization. It can also be of interest to scholars engaged in social networking discourse studies. The examples analyzed can be used in the university courses in stylistics.

\section{$5 \quad$ References}

[1] Herring, S.C., Paolillo, J.C., Ramos-Vielba, I., Kouper, I., Wright, E., Stoerger, S., Scheidt, L.A. and Clark, B. (2007). Language Networks on LiveJournal. In Proceedings of the Fortieth Hawai'i International Conference on System Sciences (HICSS-40), IEEE Press, Los Alamitos, p. 79. https://doi.org/10.1109/hicss.2007.320

[2] Haber, E.M. (2015). On the stability of online language features: How much text do you need to know a person? arXiv preprint arXiv:1504.06391.

[3] Barton, D. and Lee, C. (2013). Language Online: Investigating Digital Texts and Practices. Routledge.

[4] Scott, K. (2015). The pragmatics of hashtags: Inference and conversational style on Twitter. Journal of Pragmatics, 81: 8-20. https://doi.org/10.1016/j.pragma.2015.03. $\underline{015}$

[5] Yurina, I.A., Borodulina, N.Yu. and Makeeva, M.N. (2017). Research of social networks in the context of linguistics of new media. In Philological Sciences. Questions of Theory and Practice, Gramota, Tambov, pp. 178-181.

[6] Starbird, K., Palen, L., Hughes, A.L. and Vieweg, S. (2010). The Red: What Hazards Threat Reveals About the Social Life of Microblogged Information. In Proceedings of the ACM Conference on Computer Supported Cooperative Work, CSCW, pp. 241-250. https://doi.org/10.1145/1718918.1718965

[7] Baum, N.K. (2015). Personal Connections in the Digital Age. 2 ed. Wiley\&Sons.

[8] Kalenych, V. (2020). Cognitive and communicative pragmatic parameters of intertextuality in mass media. Psycholinguistics, 27(2): 155-173. https://doi.org/10.31470/2309-1797$\underline{\text { 2020-27-2-155-173 }}$

[9] Haas, C., Takayoshi, P., Carr, B., Hudson, K. and Pollock, R. (2011). Young people's everyday literacies: the language features of instant messaging. Research in the Teaching of English, 45(4): 378-404.

[10] Zappavigna, M. (2012). Discourse of Twitter and Social Media: How We Use Language to Create Affiliation on the Web. Bloomsbury Academic, London.

[11] Sarma, N., Singh, S.R. and Goswami, D. (2019). Influence of social conversational features on language identification in highly multilingual online conversations. Information Processing and Management, 56(1): 151-166. https://doi.org/10.1016/j.ipm.2018. $\underline{09.009}$ 
[12] Anisimova, E.E. (2003). Text Linguistics and Cross-cultural Communication (Based on Creolized Texts). Higher Education, Moscow.

[13] Ryabova, M.E. and Egorova, L.A. (2018). Polycode hypertext in polylingual discourse of intercultural communications. XLinguae, 11(2): 218-231. https://doi.org/10.18355/xl. 2018.11.02.17

[14] Tungga, S.D.S. (2018). Instagramability of javanese quotes analysis of supporting elements of Instagram posts. IOP Conference Series: Earth and Environmental Science, 175(1): 012115. https://doi.org/10.1088/1755-1315/175/1/012115

[15] Hong, L., Convertino, G. and Chi, E. (2011). Language matters in Twitter: A large scale study. In Proceedings of the Fifth International AAAI Conference on Weblogs and Social Media, AAAI Publications, 91: 518-521.

[16] Litosseliti, L. (2018). Research Methods in Linguistics. 2nd ed. Bloomsbury Academic, London, New York, Oxford, New Delhi, Sydney.

[17] Androutsopoulos, J. (2011). Language change and digital media: A review of conceptions and evidence. In Standard Language and Language Standards in a Changing Europe, Novus, Oslo, pp. 145-161.

[18] Dresner, E. and Herring, S.C. (2012). Emoticons and illocutionary force. In Philosophical Dialogue: Writing in Honor of Marcelo Dascal. College Publication, London, pp. 59-70.

[19] Decker, B.D. and Vandekerckhove, R. (2017). Global features of online communication in local Flemish: Social and medium-related determinants. Folia Linguistica, 51(1): 253-281. https://doi.org/10.1515/flin-2017-0007

[20] Gustilo, L.E. and Dino, C.M. (2017). Digitalk: An analysis of linguistic features and their functions in Filipino computer-mediated communication. Advanced Science Letters, 23(2): 1055-1059. https://doi.org/10.1166/asl.2017.7494

[21] Gabrielova, E.V. (2018). Implication and explication of evaluation as a means of speech influence (on the material of the Twitter microblog). Ph.D. diss., Moscow State Regional University, Moscow.

[22] Reyes, A., Rosso, P. and Buscaldi, D. (2012). From humor recognition to irony detection: The figurative language of social media. Data \& Knowledge Engineering, 74: 1-12. https://doi.org/10.1016/j.datak.2012.02.005

[23] Stapa, S.H. (2012). Understanding online communicative language features in social networking environment. Gema Online Journal of Language Studies, 12(3): 817-830.

[24] Volokhonsky, V.L. (2006). Psychological mechanisms and grounds for classification of blogs. In Personality and Interpersonal Interaction on the Internet. Blogs: A New Reality, SPBU Publishing House, Saint Petersburg, p. 254.

[25] Kern, L.M., McCarthy, P.X., Chakrabarty, D. and Rizoiud, M.A. (2019). Social mediapredicted personality traits and values can help match people to their ideal jobs. PNAS, 116(52): 26459-26464. https://doi.org/10.1073/pnas.1917942116

[26] Androutsopoulos, J. (2015). Networked multilingualism: Some language practices on Facebook and their implications. International Journal of Bilingualism, 19: 185-205. https://doi.org/10.1177/1367006913489198

[27] Mocanu, D., Baronchelli, A., Perra, N., Gonçalves, B., Zhang, Q. and Vespignani, A. (2013). The Twitter of babel: Mapping world languages through microblogging platforms. Plos one, 8(4): e61981. https://doi.org/10.1371/journal.pone.0061981

[28] Nurhantoro, T.S. and Wulandari, N. (2017). Exploring the use of English in Instagram and its influence on the user's identity. Journal of English Language Education, 3(2): 37-43. https://doi.org/10.26486/jele.v3i2.322

[29] Gaputina, V.A. (2018). Fashion discourse in the social network Instagram. World of Science, Culture, Education, 2(69): 526-530. 
[30] E.N. Vavilova and D.T. Huen. (2016). Ecological discourse in social networks. In International Education and Intercultural Communication: Problems, Searches, Solutions: Collection of Works of the International Scientific and Practical Conference, Tomsk, October 2627, pp. 218-222.

[31] Tarnavsky, A.A. and Filatova, O.G. (2015). Analysis of public discourse in Russian social networks around the conflict in Donbass. In State and Citizens in the Electronic Environment: Research Theory and Technology. Saint Petersburg State University Of Information Technologies, Mechanics And Optics, pp. 140-155.

[32] Kiuru, K.B. (2016). Digital-genres of modern media text: Pin, insta, twit. Sign: Problem Field of Media Education 1(18): 39-41.

[33] Goncharova, E.A. (2019). Genre-forming characteristics of the English-language microblog Twitter. Urgent Problems of Philology and Pedagogical Linguistics 3: 52-58. https://doi.org/10.29025/2079-6021-2019-3-51-58

[34] Manikonda, L., Vamsikrishna, V. and Kambhampati, M. S. (2016). Tweeting the mind and instagramming the heart: Exploring differentiated content sharing on social media. arXiv preprint arXiv:1603.02718.

[35] Idowu-Faith, B. (2016). Speaking in the Free Marketplace of Ideas: The Stylistics of Humour in "Blogversations". In Analyzing Language and Humor in Online Communication, IGI Global, pp. 65-84. https://doi.org/10.4018/978-1-5225-0338-5.ch004

[36] Kalugina, Yu.V., Mustafina, A.R. and Edeleva, I.V. (2020). Functional potential and linguistic features of modern hypertext (based on LIVE JOURNAL, TWITTER, and INSTAGRAM). Teacher of the XXI Century 2(2): 393-403. https://doi.org/10.31862/ 2073-9613-2020-2-393-403

[37] Jiang, T., Hou, Y. and Wang, Q. (2016). Does micro-blogging make us "shallow"? Sharing information online interferes with information comprehension. Computers in Human Behavior, 59: 201-214. https://doi.org/10.1016/j.chb.2016.02.008

\section{Authors}

Olga Novikova (Dr of Philology) is an Associate Professor and Head of the Department of Foreign Languages at the Federal State Budgetary Educational Establishment of Higher Education Bashkir State Agrarian University, Ufa, Russian Federation. Email: novikovaolg5@rambler.ru

Yuliya Kalugina ( $\mathrm{PhD}$ in Philology) is an Associate Professor of the Department of Foreign Languages at the Federal State Budgetary Educational Establishment of Higher Education Bashkir State Agrarian University, Ufa, Russian Federation.

Albina Mustafina ( $\mathrm{PhD}$ in Philology) is an Assistant Professor of the Department of Foreign Languages at the Federal State Budgetary Educational Establishment of Higher Education Bashkir State Agrarian University, Ufa, Russian Federation.

Irina Edeleva ( $\mathrm{PhD}$ in Philology) is an Assistant Professor of the Department of Foreign Languages at the Federal State Budgetary Educational Establishment of Higher Education Bashkir State Agrarian University, Ufa, Russian Federation.

Article submitted 2020-11-24. Resubmitted 2021-01-13. Final acceptance 2021-01-15. Final version published as submitted by the authors. 